\title{
Comparison Quality Analysis of Clean Water and Laundry Water in Bogor, Jakarta, Bekasi City and Bekasi Regency
}

\author{
Wiwit Suprihatiningsih \\ Faculty of Engineering \\ Department of Mechanical Engineering \\ Mercu Buana University, Jakarta, 11650 \\ Indonesia
}

\begin{abstract}
The limitation of high quality water reduces every year, especially in urban cities, especially in Indonesia. This research aims to determine the quality of water. Sampling method in this research is using random sampling by collect the sample at several places, such as Bogor, Jakarta, Bekasi City and Bekasi Regency. The parameters tested is a physical analysis such as temperature and EC (Electrical Conductivity). The result shown that a) the clean water and laundry water has temperature in the range of $\left.30^{\circ} \mathrm{C}-32^{\circ} \mathrm{C}, b\right) \mathrm{EC}$ value of clean water is in the range of $130-250 \mu \mathrm{S} / \mathrm{cm}$ and $E C$ value of laundry water is in the range of 310 - $440 \mu \mathrm{S} / \mathrm{cm}$. Clean water is still safe for use in daily activities and laundry water is still safe to be thrown into the environment.
\end{abstract}

Key Words: Quality, Water Analysis, Clean Water, Laundry Water.

\section{INTRODUCTION}

Projections of climate change, urban and industrial development threaten water quality and the availability of water used[13]. Population, consumption, and degradation of sources increase as if there is no limit to clean water supply[4]. The limitation of high quality of water reduce every year, especially in urban cities[5-8].

Bogor is geographically surrounded by Mount Salak, Mount Gede, and Mount Pangrango. Because it is located in the mountains, Bogor has several clean springs. Nowadays Bogor city is already crowded with population, development everywhere, and industrial sector also began to enter Bogor. Increase domestic wastes and industrial wastes make water quality decrease[5, 6 , 9].

Bekasi City is geographically located between industrial areas, densely populated settlements, and there is a final waste disposal. The area divided into 3 (three) regions and each region has different soil structures that affect water quality. Section of South Bekasi have the best water quality because it is far from industrial areas and landfills, while the section of East Bekasi and West Bekasi West near with industrial aeras and landfills that affect the quality of ground water. Most of the areas in Bekasi Regency are industrial areas and dense settlements[10]. This situation can also affect the quality of clean water[11-13].

The pace of development in Jakarta makes the need for water increases. Higher population growth leads to increased demand for development[14-19]. Residential development, malls, tall buildings, and other infrastructure make land-use changes that indirectly damage the water catchment areas[20, 21].

From environmental problems that occur, such as reduced land, reduced ground water due to large amounts of groundwater retrieval periodically, extreme weather, it would have a negative impact on the quantity and quality of ground water and surrounding environments, especially because of the climate change[22]. The negative impact is the decrease of the quality of clean water[23-27].

This study aims to assess the quality of clean water and laundry water in Bogor, Jakarta, Bekasi City, and Bekasi Regency, and compliance with water quality standards for their designated purpose. Therefore, people could identify the water quality and use it with the right way for their daily life. 


\section{METHODOLOGY}

The variables of this study consisted of temperature and EC to determine the conductivity of electric water. The number of water samples taken as many as 15 samples from each area. The total number of samples collected were 240 water samples consisting of 128 samples of clean water and 112 samples of laundry water. Samples taken randomly and taken at the same time and same source in each week.

\subsection{Place and Time Measurement}

This research is quantitative-descriptive. The study did in September 2017 until November 2017. The research location consisted of 16 areas, East Bekasi, Bantar Gebang, Cileungsi, Jonggol, Gunung Puteri, Hankam, Mustika Jaya, East Jakarta, Palm Residen Bekasi, South Cikarang, Jati Sampurna, Cibarusah, Harapan Jaya, Kp. Pisangan, South Bekasi, and Limus. These 16 areas expected to represent water conditions in Bogor, Bekasi Regency, Bekasi city and Jakarta.

Tools

1. Thermometer

To measure temperature of sample.

2. Conductometer

To measure conductivity of sample.

3. Water Container

This container as a place / container water that will be tested. It can use a glass.

\section{RESULT AND DISCUSSION}

Based on a graph, it can be seen that the clean water temperature in the Jakarta area, Bogor, and Bekasi regency in every week is relatively constant. In Bogor the highest temperature is $31.17^{\circ} \mathrm{C}$ at week 6 and lowest is $30.76^{\circ} \mathrm{C}$ at week 2 . In Jakarta the highest temperature is $31.54^{\circ} \mathrm{C}$ at week 4 and lowest is $31.42^{\circ} \mathrm{C}$ at week 1 . In Bekasi regency the highest temperature is $30.87^{\circ} \mathrm{C}$ at week 5 and low $31.43^{\circ} \mathrm{C}$ at week 3 . While in the area of Bekasi city at week 1 - week 5 water temperature relatively constant, but at week 6 water temperature rises to $31,71^{\circ} \mathrm{C}$ and at week $7-8$ water temperature drops and returns constant.

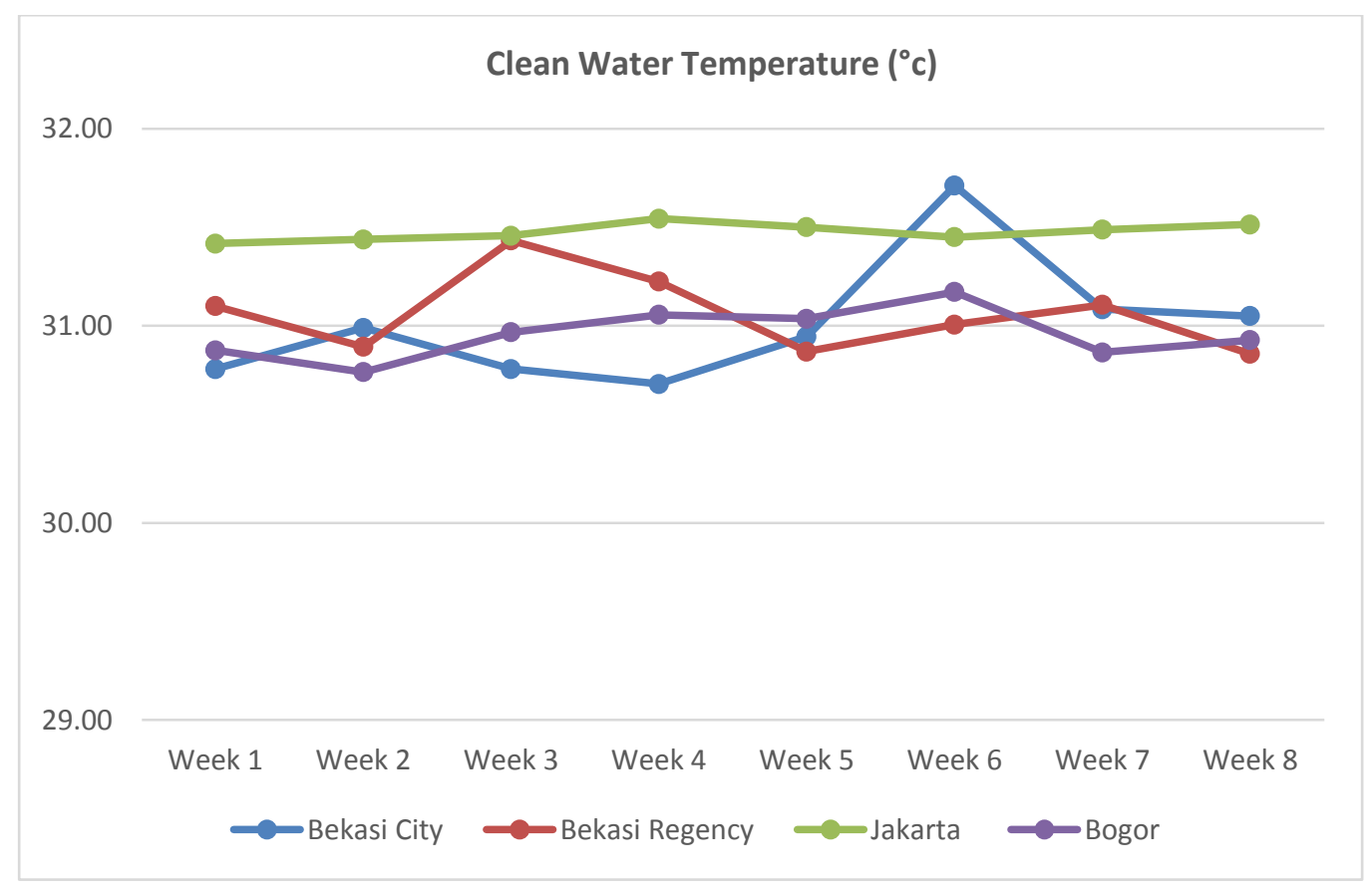

Figure 1. Graphic of clean water temperature 


\section{Laundry Water Temperature $\left({ }^{\circ} \mathrm{C}\right)$}

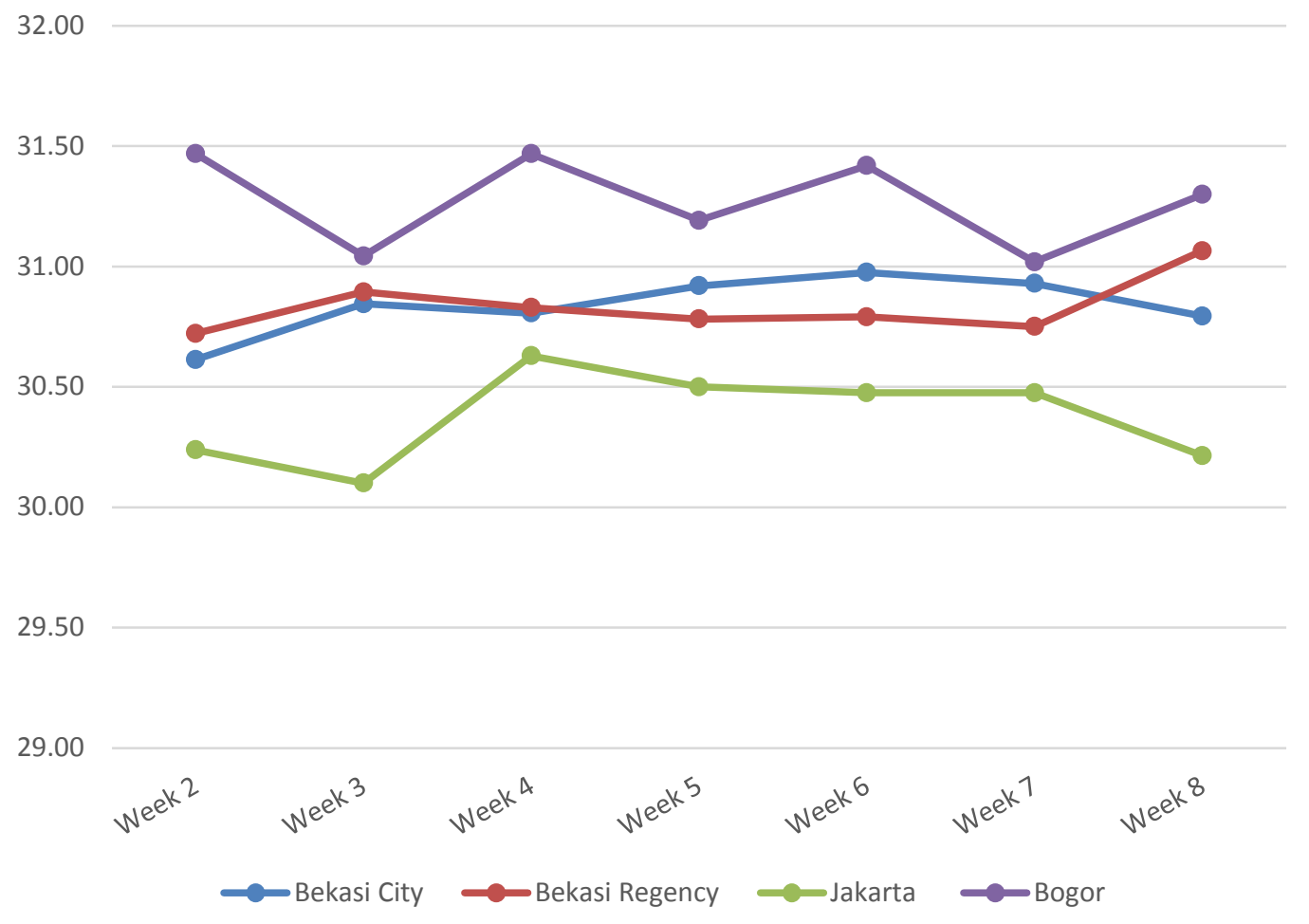

Figure 2. Graphic of laundry water temperature

Based on a graph, it can be seen that for the laundry water temperature in the Jakarta area, Bogor, Bekasi City and Bekasi regency in every week is relatively constant. In Bogor the highest temperature is $31.47^{\circ} \mathrm{C}$ at week $2 \& 4$ and lowest $31.02^{\circ} \mathrm{C}$ at week 7. In Jakarta the highest temperature is $30.63^{\circ} \mathrm{C}$ at week 4 and the lowest is $30.10^{\circ} \mathrm{C}$ at week 3 . In Bekasi Regency the highest temperature is $31.06^{\circ} \mathrm{C}$ at week 8 and low $30.72^{\circ} \mathrm{C}$ at week 2 . In Bekasi City the highest temperature is $30.97^{\circ} \mathrm{C}$ at week 6 and low $30.61^{\circ} \mathrm{C}$ at week 2 .

Based on the water quality standard Class I (Regulation No. 82 of 2001), the average temperature of water in the range of the maximum allowable temperature $\left(26-29^{\circ} \mathrm{C}\right)$. The result of clean water analysis area Bogor, Jakarta, Bekasi City and Bekasi Regency got temperature more than standard. Similarly, the results of the laundry water analysis area Bogor, Jakarta, Bekasi City and Bekasi Regency got temperature more than standard. Water temperature that exceeds the normal limit indicates that there are dissolve chemicals or these are in the process of decomposition of organic matter by microorganisms. In addition, the ambient temperature may also affect the temperature measurement of water.

Based on the graph in Figure 6, it can be seen that value of EC clean water in Bogor, Jakarta, Bekasi City, and Bekasi Regency every week is relatively constant. In Bogor the highest EC is $180.2 \mu \mathrm{S} / \mathrm{cm}$ at week 5 and the lowest EC is $171.04 \mu \mathrm{S} / \mathrm{cm}$ at week 3. In Jakarta the highest EC is $150 \mu \mathrm{S} / \mathrm{cm}$ at week 4 and the lowest EC is $131 \mu \mathrm{S} / \mathrm{cm}$ at week 7 . In Bekasi city the highest $\mathrm{EC}$ is $208.96 \mu \mathrm{S} / \mathrm{cm}$ at week 5 and lowest $\mathrm{EC}$ is $196.76 \mu \mathrm{S} / \mathrm{cm}$ at week 3 . At Bekasi Regency highest EC is $244 \mu \mathrm{S} / \mathrm{cm}$ at week 5 and lowest $\mathrm{EC}$ is $228.50 \mu \mathrm{S} / \mathrm{cm}$ at week 7 . 
International Journal of Engineering Research And Advanced Technology, Vol.5, Issue 3, March-2019

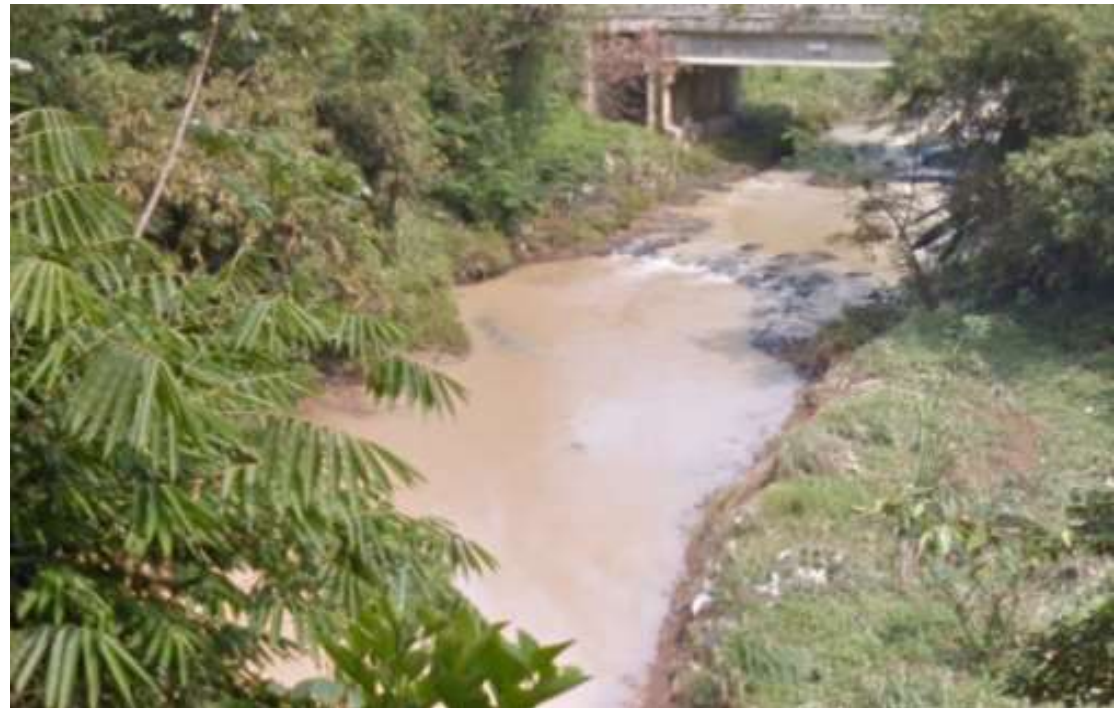

Figure 3. Condition of Cikeas River as a source of raw water in Bogor area.

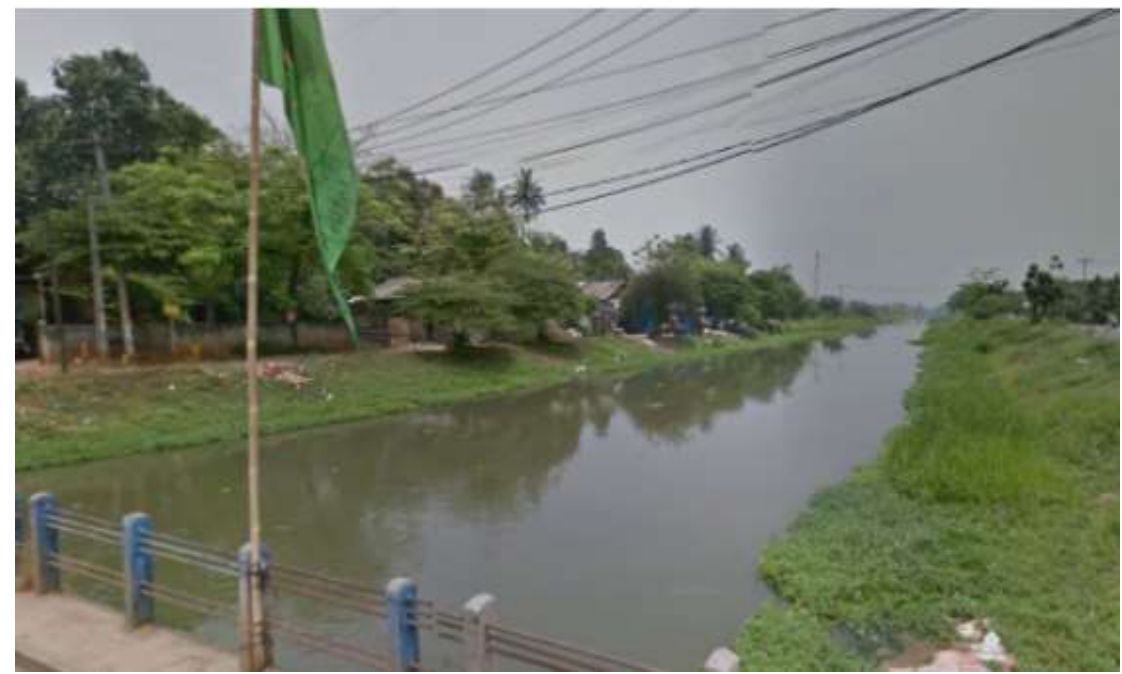

Figure 4. Condition of Ciliwung River as a source of raw water in Jakarta area.

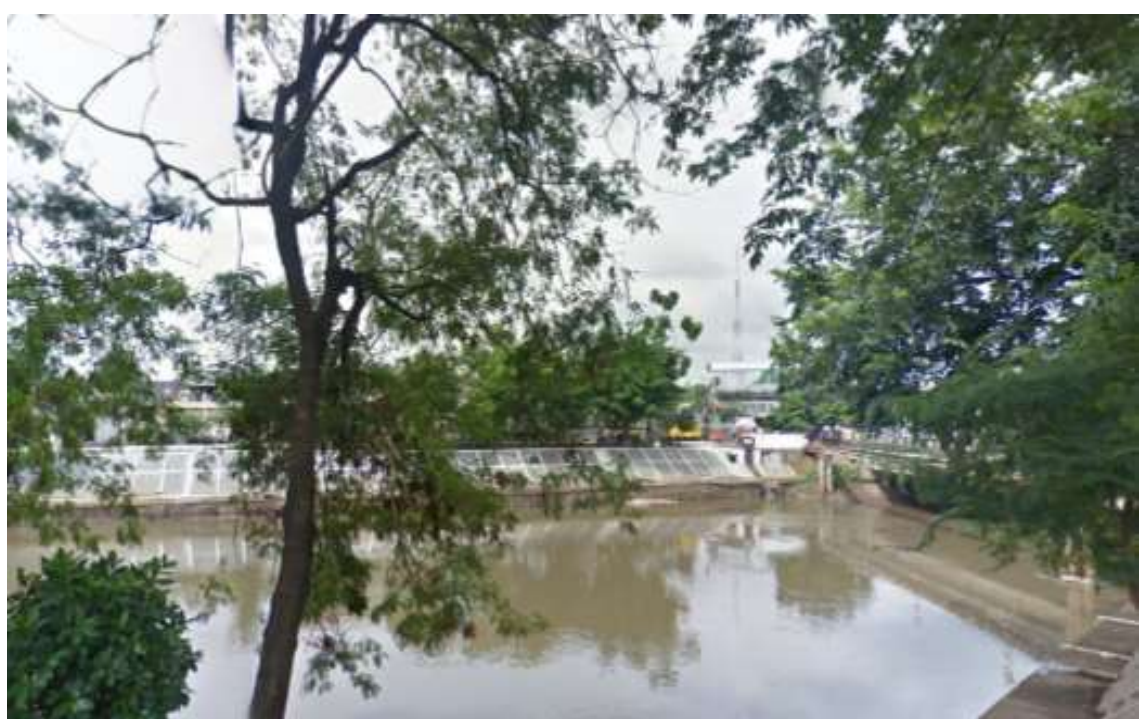

Figure 5. Condition of Kalimalang River as a source of raw water in Bekasi City and Bekasi Regency area. 


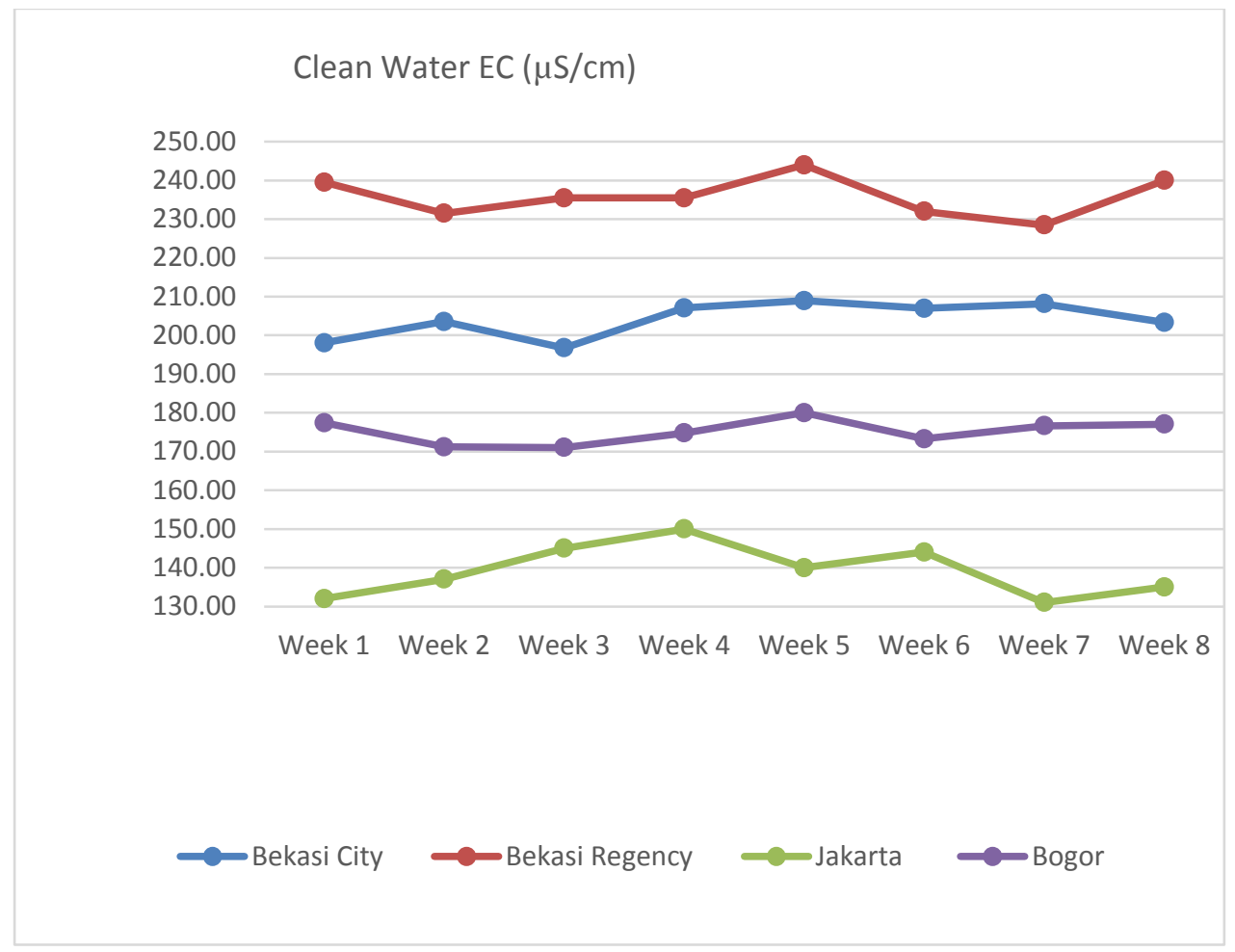

Figure 6. Graphic of clean water EC

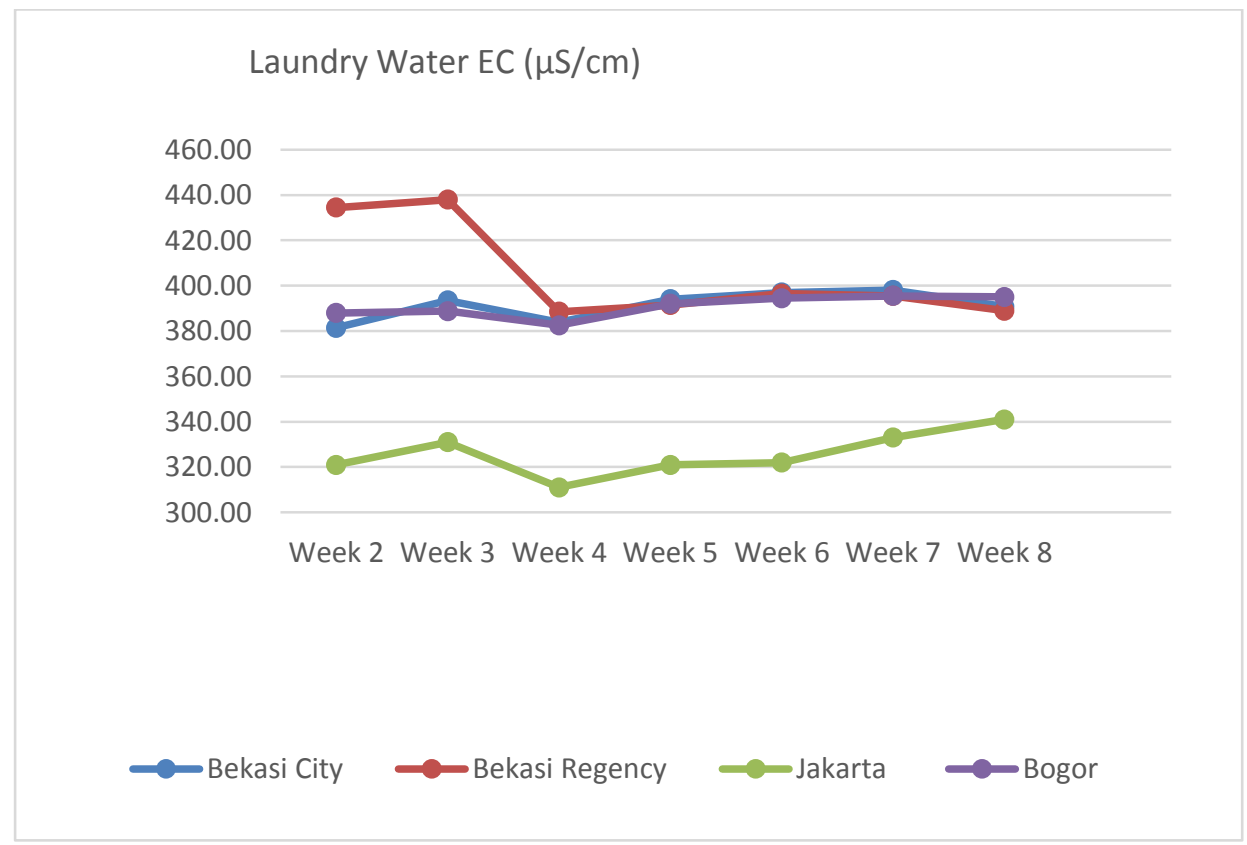

Figure 7. Graphic of laundry water EC

Figure 7 shown that the value of EC laundry water in Bogor, Jakarta, and Bekasi City every week is relatively constant. While Bekasi Regency at week 2 and week 3 has a high EC, the value are $434.50 \mu \mathrm{S} / \mathrm{cm}$ and $438.00 \mu \mathrm{S} / \mathrm{cm}$. At week 4 to week 8 the value is constant around 380-400 $\mu \mathrm{S} / \mathrm{cm}$ with the lowest EC is $388.50 \mu \mathrm{S} / \mathrm{cm}$ at week 4 . In Bogor the highest EC is 395.50 $\mu \mathrm{S} / \mathrm{cm}$ at week 7 and the lowest EC is $382.50 \mu \mathrm{S} / \mathrm{cm}$ at week 4 . In Jakarta the highest EC is $341 \mu \mathrm{S} / \mathrm{cm}$ at week 8 and the lowest is $311 \mu \mathrm{S} / \mathrm{cm}$ at week 4 . In Bekasi city the highest EC is $398.11 \mu \mathrm{S} / \mathrm{cm}$ at week 7 and the lowest EC is $381.44 \mu \mathrm{S} / \mathrm{cm}$ at week 2 .

Standard EC according to PPRI No. 20 of 1990 about Water Pollution Control is $2250 \mu \mathrm{S} / \mathrm{cm}$ class D (water that can be used for agricultural purposes as well as urban, industrial, and power plant), while its natural content is $20-1500 \mu \mathrm{S} / \mathrm{cm}$ ( natural waters)[28].

The results of clean water analysis in the area Bogor, Jakarta, Bekasi City, and Bekasi Regency are all in accordance with standard PPRI No. 20 Year 1990. Similarly ,the results of the analysis of laundry water in Bogor, Jakarta, Bekasi City, and Bekasi Regency are all in accordance with standard. The value of EC is influenced by the amount of dissolved salt. The more dissolved 
salts that can be ionized, the higher EC value. EC values are closely related to TDS values. The TDS value can be estimated by multiplying the EC value by the numbers $0.55-0.75$. TDS value is usually smaller than the value of EC. So it can be said that the TDS Value of clean water and laundry water of all regions is theoretically in accordance with the standard.

The use of EC as a water quality parameter aims to measure the ability of ions in water to conduct electricity and predict mineral content in water[29]. The measurements are based on the cation and anion ability to conduct the electric current flowing in the water samples can be used as indicators, where by the greater electrical conductivity value indicated in conductometer, the greater abilities of cation and anion present in the water sample to conduct electrical current. This indicates that more minerals contained in water.

\section{CONCLUSION}

1. Clean water and laundry water has high temperature more than the normal limit.

2. EC value of clean water and laundry water still within range of normal limit.

3. Clean water is still safe for use in daily activities.

4. Laundry water is still safe to be thrown into the environment.

\section{ACKNOWLEDGMENT}

This research was supported by The Students of Chemistry and Environmental Study Class Reg 2 \& Industrial Chemistry Class Reg 1: Gasal/2018-2019, University of Mercu Buana, Kampus D, Indonesia.

\section{REFERENCES}

[1] T. Izzati, W. Suprihatiningsih, and A. P. S. Subarno, "Further study of ground water quality in industrial area of Bekasi and residential area of Depok, West Java, Indonesia." p. 012023.

[2] W. Suprihatiningsih, T. Izzati, and B. Santoso, "Analysis Of Groundwater Quality In Industrial Of Bekasi Regency And Residential Of Bekasi City, West Java, Indonesia." p. 012044.

[3] N. E. Triana, T. Izzati, and A. Hartanto, "Analysis of Groundwater Quality in an Industrial Location at MM2100 and a Residential Location at Cibuntu, West Java, Indonesia." p. 012041.

[4] S. D. Richardson, and T. A. Ternes, "Water analysis: emerging contaminants and current issues," Analytical chemistry, vol. 86, no. 6, pp. 2813-2848, 2014.

[5] M. E. Beatrix, T. Izzati, F. A. Razak et al., "Analysis of Water Quality to Industrial and Residential Development Area in Bogor, West Java, Indonesia (A Case Study),” Science International, vol. 30, no. 1, pp. 159-1661, 2018.

[6] T. Izzati, "Water Quality Analysis Of Residential And Industrial Areas In Bogor, West Java, Indonesia," Science International, vol. 29, no. 2, pp. 37-370, 2017.

[7] T. Izzati, “An Initial Study Of The Air Pollution Through Rainwater In An Industrial Area Of Cikarang, West Java, Indonesia (A Case Study)," Science International, vol. 28, no. 4, 2016.

[8] S. Maryati, A. N. S. Humaira, and K. R. Hudiary, "Faktor-Faktor Yang Mempengaruhi Cakupan Pelayanan Air Bersih Di Kawasan Metropolitan Di Indonesia,” Simposium II UNIID 2017, vol. 2, no. 1, pp. 248-253, 2017.

[9] T. Izzati, "An Initial Study of the Water Pollution Analysis at Residential, Office Building and Industrial Area's in Bogor," World Chemical Engineering Journal, vol. 1, no. 4, 2017.

[10] R. J. Klancko, "Hazardous Waste Operations and Emergency Response Manual and Desk Reference. EE Hackman, CL Hackman, and ME Hackman. 2002. McGraw-Hill, New York. 544 pp. $\$ 99.95$ hardcover,” Environmental Practice, vol. 4, no. 03, pp. 174-175, 2002.

[11] T. Izzati, “An Initial Study Of The Air Pollution Through Rainwater In An Industrial Area Of Bekasi,” World Chemical Engineering Journal, vol. 1, no. 2, 2016.

[12] T. Izzati, N. E. R. Wuryandari, S. Ayudia et al., "An Initial Study Of Laundry Industrial Effects To The Water Pollution In Bekasi,” IOSR Journal of Business and Management, vol. 18, no. 8, pp. 109-111, 2016.

[13] T. Kadri, S. D. Tarigan, N. Sinukaban et al., “Analisis Kapasitas Dan Kecepatan Aliran Sungai Bekasi Hulu,” 2009. 
[14] W. Suprihatiningsih, T. Izzati, K. Y. Utomo et al., "The Factors Influences of pH or Acidity Level in The Urban Area," Advances In Natural And Applied Sciences, vol. 12, no. 4, pp. 3-43, 2018.

[15] W. Suprihatiningsih, T. Izzati, A. R. A. P. B. E. Pambudi et al., “Analytical Report on Water Quality of Residential and Industrial Area of East Jakarta, Jakarta, Indonesia,” Science International, vol. 30, no. 1, pp. 169-172, 2018.

[16] T. Izzati, K. Y. Utomo, P. Hastuti et al., “An Initial of the Pollution of Water in Industrial Area Surronding Coastal Zone of North Jakarta, Indonesia,” Science International, vol. 30, no. 2, pp. 325-328, 2018.

[17] T. Izzati, W. Suprihatiningsih, A. R. A. Pratama et al., “Analytical Report On Water Quality Of Residential And Industrial Area Of East Jakarta, Jakarta, Indonesia,” Science International, vol. 30, no. 1, pp. 169-172, 2018.

[18] T. Izzati, W. Suprihatiningsih, W. Satuti et al., “An Initial Study Of Industrial Area's Effects For The Air Pollution Through Rainwater In East Jakarta,” IOSR Journal of Mechanical and Civil Engineering, vol. 13, no. 4, pp. 159-162, 2016.

[19] T. Izzati, W. Suprihatiningsih, M. Kristovorus et al., “An Initial Study Of Laundry Industrial Effects To The Water Pollution In East Jakarta,” IOSR Journal of Environmental Science, Toxicology and Food Technology vol. 10, no. 9, pp. 35-37, 2016.

[20] T. Izzati, and Y. Poerwanti, "Enhancing The Productivity And Multifunctionality Of Open Space Using Simple Techniques In Green Buildings,” Science International, vol. 26, no. 2, pp. 689-690, 2014.

[21] A. F. Zain, P. A. Permatasari, C. N. Ainy et al., "The detection of urban open space at Jakarta, Bogor, Depok, and Tangerang-Indonesia by using remote sensing technique for urban ecology analysis," Procedia Environmental Sciences, vol. 24 , pp. 87-94, 2015.

[22] R. Nugroho, "Pemasyarakatan Daur Ulang Air Limbah Untuk Mengantisipasi Kelangkaan Air Akibat Perubahan Iklim Global," Jurnal Air Indonesia, vol. 7, no. 1, 2018.

[23] A. Herlambang, "Pencemaran air dan strategi penggulangannya," Jurnal Air Indonesia, vol. 2, no. 1, 2018.

[24] Standar Baku Mutu Kesehatan Lingkungan dan Persyaratan Kesehatan Air untuk Keperluan Higine Sanitasi, Kolam Renang, Solus Per Aqua, dan Pemandian Umum, 2017.

[25] M. K. R. Indonesia, "Peraturan Menteri Kesehatan No. 416 Tahun 1990 Tentang: Syarat-syarat Dan Pengawasan Kualitas Air," 2016.

[26] A. F. Widiyanto, S. Yuniarno, and K. Kuswanto, "Polusi Air Tanah Akibat Limbah Industri dan Limbah Rumah Tangga,” Jurnal Kesehatan Masyarakat, vol. 10, no. 2, pp. 246-254, 2015.

[27] M. N. L. Hidup, "Keputusan Menteri Negara Lingkungan Hidup No. 115 Tahun 2003 Tentang Pedoman Penentuan Status Mutu Air," Jakarta: Menteri Negara Lingkungan Hidup, 2003.

[28] A. Endo, I. Tsurita, K. Burnett et al., "A review of the current state of research on the water, energy, and food nexus," Journal of Hydrology: Regional Studies, vol. 11, pp. 20-30, 2017.

[29] F. Edition, "Guidelines for drinking-water quality," WHO chronicle, vol. 38, no. 4, pp. 104-8, 2011. 